\title{
The abandonment of the Spitzenkandidaten System: (Un)sustainable democracy in the EU?
}

\author{
El abandono de los Spitzenkandidaten: \\ ¿Democracia (in)sostenible en la UE?
}

\author{
Dr. Carlos Espaliú Berdud \\ Catedrático/Investigador Principal del Grupo de Seguridad, Gestión de Riesgos y Conflictos \\ (SEGERICO) \\ cespaliu@nebrija.es
}

Summary: I. Introduction.-II. Toward a more sustainable democracy in the EU: Article 17.7 TEU and the Spitzenkandidaten system. 1. Article 17.7 TEU and the Spitzenkandidaten system in the context of reinforcing the direct participation of citizens in the EU's political procedures. Theoretical grounds. 2. The «success» of the Spitzenkadidaten system in 2014. Empirical results. - III. The fall of the Spitzenkandidaten system: toward a more (un)sustainable democracy in the EU? 1. The tension between the European Parliament and the European Council with regard to the Spitzenkandidaten system. Theoretical and power disputes. 2. The abandonment of the Spitzenkandidaten system in 2019. Empirical results of the disputes.-IV. Conclusion.

\footnotetext{
Abstract: In the process of the parliamentarisation of the EU, the Treaty of Lisbon took a further step forward by introducing into the founding treaties Article 17.7 TEU- the need to take into account the elections to the European Parliament for the appointment of the President of the Commission. Nevertheless, the European Parliament has been trying to impose its interpretation of Article 17.7 TEU, which has been coined into the Spitzenkandidaten doctrine, according to which the head of the party winning the elections should be elected as Commission President. The Parliament succeeded in imposing its vision with the occasion of the appointment of Juncker in 2014. Nevertheless, by not proposing Manfred Weber, the leader of the most voted party in the 2019 elections, as President, the European Council has prevented the consolidation of the 2014 precedent. Article 17.7 of the TEU also expresses the desire to bring the European elections closer to the citizens, so that their opinion is taken into account when the President of the Commission is elected. And it seems that both the results of participation in 2019 and the perception of the voters show that the Spitzenkandidaten system has been useful for that purpose. In any event, I consider that the fact that citizens voted in the 2019
} 
elections in the belief that their votes would be decisive in appointing the President of the Commission and, in the end, it was not elected an Spitzenkandidaten as head of the Commission, is a very serious lack of consideration for citizens.

Keywords: Participatory Democracy; European Citizens' Initiative; Spitzenkandidaten; single European constituency.

Resumen: En el proceso de parlamentarización de la UE, el Tratado de Lisboa dio un nuevo paso adelante al introducir en los tratados constitutivos - Artículo 17.7 TEU - la necesidad de tener en cuenta las elecciones al Parlamento Europeo a la hora de nombrar al Presidente de la Comisión. Sin embargo, el Parlamento Europeo ha intentado imponer su interpretación del artículo 17.7 TUE, que ha sido acuñada en la doctrina Spitzenkandidaten, según la cual el jefe del partido que gana las elecciones debe ser elegido como Presidente de la Comisión. El Parlamento logró imponer su visión con ocasión del nombramiento de Juncker en 2014. Sin embargo, al no proponer como Presidente a Manfred Weber, el líder del partido más votado en las elecciones de 2019, el Consejo Europeo ha impedido la consolidación del precedente de 2014. El artículo 17.7 del TUE expresa también el deseo de acercar las elecciones europeas a los ciudadanos, para que su opinión sea tenida en cuenta en la elección del Presidente de la Comisión. Y parece que tanto los resultados de la participación en 2019 como la percepción de los votantes muestran que el sistema de Spitzenkandidaten ha sido útil para ese fin. En cualquier caso, considero que el hecho de que los ciudadanos hayan votado en las elecciones de 2019 en la creencia de que sus votos serían decisivos para designar al Presidente de la Comisión y, al final, no se haya elegido a un Spitzenkandidaten como jefe de la misma, es una falta de consideración muy grave en relación con los ciudadanos.

Palabras clave: Democracia participativa; Iniciativa ciudadana europea; Spitzenkandidaten; Circunscripción común única.

\section{Introduction}

In recent decades, democracy and the rule of law have been some of the most cherished values among the European population ${ }^{1}$. Therefore, among other things, the debate about democratic legitimacy ${ }^{2}$ in the process of

${ }^{1}$ For example, one of the Commission's latest special Eurobarometers shows that a large proportion of citizens regard respect for democracy, human rights and the rule of law as the main asset of the European Union. In this regard, see: European Commission, Special Eurobarometer 479, Future of Europe, October-November 2018: 20.

${ }^{2}$ In this article we will embrace the meaning of legitimacy by focusing on procedural and representative aspects. In that sense, we can say that the EU will have legitimacy, like any political system, insofar as citizens feel that they are participating directly or indirectly in the decision-making procedures and in the formation of the rules of their legal system. Of course, the possibility of effective participation by citizens in the political system is inversely proportional to their size and the distance between the decision-making centres 
European integration embodied in the European Communities, and today in the European Union (EU), has been a constant from its first steps. In general, during the first decades of its existence, the European Communities were blamed for receiving power from the Member States, which were required to function democratically, but then this power was exercised in the Communities by institutions other than the European Parliament ${ }^{3}$, so that its democratic functioning was far from evident. Rather, one would say that the Communities were governed by management models that are more intergovernmental than democratic. Later, once the European Communities had developed and settled, the accusation also arose of the over-dimensioning of the Brussels bureaucratic apparatus, which controls all the Union's machinery from its ivory tower, far removed from the reality of citizens ${ }^{4}$. It is clear that the accusations of distancing from citizens by Communities spheres and actors when it comes to management, and the institutional model clearly intergovernmental, would be fed back, contributing in an ominous way to an image of lack of democratic legitimacy of the institutions of the Communities. Logically, this characterization is very dangerous for the future of integration, since one of the virtues of legitimacy in the framework of a political system is to unite those who govern and those who are governed ${ }^{5}$. If this perception, which is so common among citizens, of the Union's lack of legitimacy were to become consolidated, it would generate a detachment among the governed towards the international organisation, a situation that could lead to the departure of the Member States, as has occurred in the case of the

and themselves. In the case of the EU, due to the nature of things, as the international organisation is a gigantic political system of a supranational nature, the participation of individuals in the running of the organisation is not easy.

3 European Parliament, "Resolution on the Democratic Deficit in the European Community”, Doc. A-2-276/87, June 1988, pars. 10-11, OJ C 187, 18 July 1988.

${ }^{4}$ On this point see: Christian Rauh, "No longer an ivory tower: How public debates influence European Commission policies", Evidence-based analysis and commentary on European Politics, London School of Economics and Political Sciences, accessed on 21/09/2020, https://blogs.lse.ac.uk/europpblog/2016/09/07/no-longer-an-ivory-tower-ec/. On the debate about the democratic deficit of the EU, see also, among others: Giandomenico Majone, "Europe's "Democratic Deficit": The Question of Standards", European Law Journal, 4: 1 (1998): 5-28; Andrew Moravscik, "In Defence of the Democratic Deficit: Reassessing Legitimacy in the European Union", Journal of Common Market Studies 40: 4 (2002): 603-634; Andreas Follesdal; Simon Hix, "Why there is a democratic deficit in the EU: A response to Majone and Moravcsik", Journal of Common Market Studies 44: 3 (2006): 533-562.

5 Javier Arregui Moreno, "Problemas de legitimidad democrática, representación y rendimiento de cuentas en el proceso político de la Unión Europea", Cuadernos Europeos de Deusto 46 (2012): 88-89. 
United Kingdom, or take the phenomenon to the extreme, to the very death of the international organisation ${ }^{6}$.

Having warned of the danger of the Union's lack of legitimacy, we must move forward by explaining that this has been overcome historically in various ways, although in the background there is an ambition to give greater weight to citizens' opinions in European policy.

Firstly, the aim was to increase the weight of citizens' opinion by making them more representative in the European Parliament through the organisation of direct elections, as well as by giving more powers to the European Parliament itself - the institution which must defend the interests of the citizens - in the institutional firmament of the Communities. As it was stressed by the European Parliament itself in its Resolution of 1988 on the Democratic Deficit, that problem could "[...] be remedied only at the level of the Community itself, by a redistribution of powers between the Council and Parliament; [...]"7. That program has been implemented through the successive Treaty reforms, and today it can be perceived in the multiple and relevant competences settle down in article 14.1 of the Treaty on European Union (TEU). Mainly in the decisive involvement of the European Parliament in the legislative procedure ${ }^{8}$, but also in its increased competences regarding the nomination process of the Commission (Article 17. 7 TEU) and its control over it, including the possibility of motion of censure (Article 17. 8 TEU and Article 234 Treaty on the Functioning of the European Union (TFEU)). Thus, the times when Parliament played only

${ }^{6}$ With regard to European integration, Luis Bouza considers that it suffers from a lack of popular support, motivated not so much by the institutional structure and its functioning, but by the citizens' perception of this architecture and its work. In this author's opinion, the problem of the EU's lack of legitimacy is sociological and political in nature, rather than constitutional or institutional, and therefore institutional responses are not sufficient to solve it; it would be necessary to implement solutions that make political sense of the Union. In this regard, see: Luis Bouza García, "Democracia participativa, sociedad civil y espacio público en la Unión Europea. Algunas propuestas para el desarrollo del artículo 11 TUE del Tratado de Lisboa", Estudios de Progreso. Fundación Alternativas 57 (2010): 14-15.

7 European Parliament, "Resolution on the Democratic Deficit in the European Community...": par. 20. According to Prieto and Abad, there is a widespread perception that the more parliamentary the system is, the more democratic the EU will be, as Parliament is the only directly elected institution of the Union, which will at the same time make the European Union more legitimate and sustainable. In this regard see: Alberto Priego; Gracia Abad, "La parlamentarización del sistema político de la Unión Europea: sus consecuencias para la legitimidad", Cuadernos Europeos de Deusto 52 (2015): 18.

8 On this issue, see: Gregorio Garzón Clariana, "El Parlamento Europeo y la evolución del poder legislativo y del sistema normativo de la Unión Europea", Revista de Derecho Comunitario Europeo 50 (2015): 43-83. 
a secondary role, essentially of a consultative nature, remain as a distant memory of the founding era 9 .

Secondly, the increase in the weight of citizens' opinion has been sought, particularly in recent times, through the promotion of direct participation by citizens in the Union's political procedures. In this regard, it must be underlined the relevant impulse given by the Lisbon Treaty by setting up the European citizens' initiative of Article 11.4 of the TEU and 24 TFEU $^{10}$ and opening the door to the possibility that the European citizens could have a voice in the nomination of the President of the Commission by Article 17.7 TEU. That article is as follows:

Taking into account the elections to the European Parliament and after having held the appropriate consultations, the European Council, acting by a qualified majority, shall propose to the European Parliament a candidate for President of the Commission. This candidate shall be elected by the European Parliament by a majority of its component members. If he does not obtain the required majority, the European Council, acting by a qualified majority, shall within one month propose a new candidate who shall be elected by the European Parliament following the same procedure.

The rather vague expression of the first phrase of Article 17.7 TEU - "Taking into account the elections..." - needed to be interpreted and translated into practice on the first possible occasion after the entry into force of the Treaty of Lisbon, in the 2014 elections to the European Parliament. It was implemented by appointing as President of the Commission the head of the list of the party with the most votes in those elections, after complicated internal candidate selection processes by the large European parties. That interpretation of Article 17.7, patronized by

9 About the process of gaining of competences by the European Parliament, see: Enrique Barón Crespo, "El desarrollo de la codecisión como procedimiento legislativo de la UE", Cuadernos Europeos de Deusto 46 (2012): 19-47.

${ }^{10}$ Under these rules, one million Union citizens, who are nationals or permanently resident in at least one quarter of the Member States may call on the Commission to submit a proposal for a legal act they consider necessary to implement the Constitutive Treaties of the Union. On the European citizens' initiative, see, among others: Andres Auer, "European Citizens' Initiative", European Constitutional Law Review 1: 1 (2005): 79-86; Luis Bouza Garcia; Justin Greenwood, "The European Citizens' Initiative: A new sphere of EU politics?", Interest Groups \& Advocacy 3 (2014): 246-267; Víctor Cuesta López, "The Lisbon Treaty's Provisions on Democratic Principles: A Legal Framework for Participatory Democracy", European Public Law Review 16: 1 (2010): 123-138; Nicolas Levrat, "L'initiative citoyenne européenne: une réponse au déficit démocratique?", Cahiers de droit européen 47: 1 (2011) : 53-101. 
the Parliament, has been coined in the so call, with the German name, Spitzenkandidaten system.

We will consecrate this paper to the study of the scope of Article 17.7 TEU and the Spitzenkandidaten system when it comes to the participation of citizens in the political functioning of the EU. Particular attention will be given to the effects of the abandonment of the Spitzenkandidaten system after the European Parliament elections of 2019 in the light of the sustainability of democracy in the EU. Indeed, after having had internal election in the main European parties before the European Parliament 2019 elections and presented the resulting leaders as candidates for the post of President of the Commission, the European Council did not follow the results of the elections. It did not nominate the leader of the European People's Party (EPP), who was the winner of the elections to the European Parliament, nor another Spitzenkandidaten of the new majority as President of the Commission. This non-respect of the citizens' opinion could be taken for a serious blow to the democracy in the EU, even more when the citizens have voted under the conviction that their will would be taken into account with regard to the nomination of the President of the Commission. To complete the perspective of the gravity of the EU institutions conduct, it should also be highlighted the fact that, for the first time since 1979, in 2019 elections the turnout was higher than in 2014.

Thus, in the following section we will present the Article 17.7 TEU and the Spitzenkandidaten system in the framework of the direct participation of citizens in the EU political activity and its implementation during the 2014 European Parliament elections. In the third section, we will first shed light over the conflict between the European Parliament and the European Council regarding the interpretation of Article 17.7 TEU and its implementation during the upcoming 2019 election to the European Parliament. Second, we will have a look onto the non-respect of the Spitzenkandidaten system after the European Parliament 2019 elections and the nomination of the candidate proposed by the Members States for the post of President of the Commission instead of the one chosen by the citizens. Finally, we will present our conclusions over the effect of the abandonment of that system for the sustainability of the democracy in the EU.

Finally, with regard to the methodological aspects, as EU Law is a branch of Public International Law, we will use the methodology proper to this legal science: the study of the creative process of legal rules, their interpretation and application, in their historical and sociological context. In this methodological journey, we will use the presentation of the various theoretical conceptions of what is understood by democratic functioning within the EU, complementing the ideas already set out in this introduction on the subject. We will also examine the empirical results of the 
interpretative and power battles between EU institutions in the context of European citizens' participation in the democratic life of the Union.

\title{
II. Toward a more sustainable democracy in the EU: Article 17.7 TEU and the Spitzenkandidaten system
}

\author{
1. Article 17.7 TEU and the Spitzenkandidaten system in the context of \\ reinforcing the direct participation of citizens in the EU's political \\ procedures. Theoretical grounds
}

As has been already stated above, in order to deepen the ways in which the democratic legitimacy of the Union could be enhanced, the Treaty of Lisbon introduced in the founding treaties a provision whereby the voice of the European citizens should be heard with regard to the President of the Commission's nomination ${ }^{11}$.

The new provisions of Article 17.7 of the TEU seem to have their origin in point 47 of a document called "A Constitution for a Strong Europe" presented in Estoril (Portugal) in October 2002 during a meeting of the EPP in preparation for the Convention on the Future of Europe. That article, which was produced seeking to introduce greater democratic legitimacy into the European elections, reads as follows:

47. A candidate for the President of the European Commission should be proposed to the European Parliament by the European Council in light of the outcome of European elections, and by qualified majority vote. The European Parliament should give or withhold its approval by majority vote. This would give European political parties the opportunity to present their own candidates in the framework of the campaign for European elections. It would ensure a more personalised election campaign and increase democratic control and support of the European Commission. ${ }^{12}$

11 Of course, as Sophia Russack has put it: "The Spitzenkandidaten system implicitly promotes the 'parliamentarisation' of the EU and a federal model of European democracy [...].", see: Sophia Russack, "EU parliamentary democracy: how representative?", CEPS Policy Insights No. 2019-07 / May 2019: 10.

12 See: European Popular Party, Factsheet "The Story of the 'Spitzenkandidaten'”, June 2014: 2. Subsequently, in December 2002, during the Convention, the EPP faction proposed an article 78 (3) in the draft Constitution along the following lines: "(3) A candidate for the President of the Commission shall be proposed to the European Parliament by the Council, acting by qualified majority, in the light of the results of the European Parliament elections. To become President of the Commission, the proposed candidate requires the approval of an absolute majority of the members of the European Parliament." (Ibid.) The Praesidium of 
The successful initiative moved from the EPP meeting in 2002, during the Convention process, to the Intergovernmental Conference, then to the 2004 Treaty itself and then, as we have seen, to the founding treaties by the Treaty of Lisbon.

Notwithstanding that inception in the European framework, the idea has probably its roots in national politics. Perhaps in the proposal made in 1997 during the general convention of Germany's Christian Democratic Union party (CDU) of putting forward a "top candidate" in the European elections who would go on to become President of the European Commission, should the party win the elections ${ }^{13}$.

Moving forward to Article 17.7 TEU interpretation, it has to be noted that there is a difference between the initial text of the 2002 EPP meeting and the final text approved by the Intergovernmental Conference, which was introduced at the time of the Convention. In the first text, the expression "in light of the outcome of European elections..." seems to be a little bit stronger in the sense of obligation than the one finally adopted at the Convention, "Taking into account the result of the elections to the European Parliament...”.

the Convention included the proposal in its April 2003 draft (ibid.) and it eventually became Article 26 (1) of the final text adopted by the Convention: "Article 26: The President of the European Commission 1. Taking into account the elections to the European Parliament and after appropriate consultations, the European Council, deciding by qualified majority, shall put to the European Parliament its proposed candidate for the Presidency of the Commission. This candidate shall be elected by the European Parliament by a majority of its members. If this candidate does not receive the required majority support, the European Council shall within one month propose a new candidate to the European Parliament, following the same procedure" (ibid.: 3). Finally, the idea was taken up in Article I-27 (1) of the text adopted by the 2004 Intergovernmental Conference as the Treaty establishing a Constitution for Europe (see ibid.), which reads as follows: "The President of the European Commission: 1. Taking into account the elections to the European Parliament and after having held appropriate consultations, the European Council, acting by a qualified majority, shall propose to the European Parliament a candidate for President of the Commission. This candidate shall be elected by the European Parliament by a majority of its component members. If he or she does not obtain the required majority, the European Council, acting by qualified majority, shall within one month propose a new candidate who shall be elected by the European Parliament following the same procedure" (ibid.).

${ }^{13}$ In that sense, see: European Commission, European Political Strategy Centre, Building on the Spitzenkandidaten Model. Bolstering Europe's Democratic Dimension, Issue 1 February 2017: 3, accessed on 23 September 2020, http://www.politico.eu/wp-content/ uploads/2018/02/Spitzenkandidaten.pdf. The idea was endorsed by a petition from the Jacques Delors Notre Europe Institute in 1998, signed by Tommaso Padoa-Schioppa: Jacques Delors - Notre Europe, 1998, "From the single currency to the single ballot box", accessed on 23 September 2020: http://institutdelors.eu/wp-content/uploads/2018/01/tps-ceo1998-ensinglecurrencyandelections.pdf 
Moreover, as Martin Westlake has stressed, in some language versions (for example, English, French, Italian) of what is now Article 17.7 TEU, the European Council proposes a candidate for the Presidency of the European Commission after "taking into account the elections". And yet in other language versions (German and Spanish, for example), the Article talks about "taking into account the result of the elections". For him, "taking into account the elections" could mean ensuring a balance of the best-performing political families when making nominations to that position. While "taking into account the result" "[...] could only mean, more narrowly, nominating for the Presidency of the Commission the representative of the political family which had won the most seats". ${ }^{14}$

Article 17.6 and 17.7 TEU were complemented, in theory, by Declaration 11 annexed to the Final Act of the Intergovernmental Conference which adopted the Treaty of Lisbon ${ }^{15}$. The wording of the Declaration 11 does not shed light over the key issue, that is whether or not the European Council must follow the results of the European Parliament elections in order to nominate the President of the Commission. The text only indicates that "[...] the European Parliament and the European Council are jointly responsible for the smooth running of the process leading to the election of the President of the European Commission"16. During that process, some consultations between the two institutions are foreseen, with the only indication that they will focus "on the backgrounds of the candidates for President of the Commission, taking account of the elections to the European Parliament, in accordance with the first subparagraph of Article 17(7)" $" 17$.

${ }^{14}$ See: Martin Westlake, "Chronicle of an Election Foretold: The Longer-Term Trends leading to the Spitzenkandidaten Procedure and the Election of Jean-Claude Juncker as European Commission President", LSE Europe in Question Paper Series 102 (2016): 39-40.

15 "11. Declaration on Article 17(6) and (7) of the Treaty on European Union. The Conference considers that, in accordance with the provisions of the Treaties, the European Parliament and the European Council are jointly responsible for the smooth running of the process leading to the election of the President of the European Commission. Prior to the decision of the European Council, representatives of the European Parliament and of the European Council will thus conduct the necessary consultations in the framework deemed the most appropriate. These consultations will focus on the backgrounds of the candidates for President of the Commission, taking account of the elections to the European Parliament, in accordance with the first subparagraph of Article 17(7). The arrangements for such consultations may be determined, in due course, by common accord between the European Parliament and the European Council" (Declarations annexed to the Final Act of the Intergovernmental Conference which adopted the Treaty of Lisbon, signed on 13 December 2007, OJ C 32626 October 2012).

16 Ibid.

17 Ibid. 
Obviously, one can conclude on this point, that the idea behind the original text of the EPP, along the lines of the CDU proposal, was that the leader of the party who would win the elections to the Parliament should be proposed by the European Council as the candidate for the office of President of the Commission. Nevertheless, even if that intention would have remained implicit in the final text of Article 17.7 TEU, the wording -at least in the English version- indicates only the necessity of dialogue between the European Council and the European Parliament, taking into account the results of the elections. From the wording cannot be inferred that the winner of the election must automatically be nominated as Commission President. Furthermore, in any case, in no place is said that taking into account the result of the elections implies to appoint the head of the winner party; it could be the leader of the majority, even if it is the leader of another party forming the majority in the Parliament after the elections ${ }^{18}$.

In my opinion, the lowest level of influence of the results in the appointment as President of the Commission would be to nominate someone from the party or parties forming the new majority; better of the winner, even if he or she had not been a candidate in the elections. Nevertheless, while this possibility would be acceptable, if we look at the text of Article 17.7 TEU, it would probably be contrary to the spirit of the changes, and certainly it would leave people unsatisfied. Indeed, one might think that in the end, Commission Presidents have usually come from politicians from the ranks of parties in the EPP or the S\&D. Then, what is the point of having made the changes to the Treaties to nominate again someone from those parties when they are most likely still the winners of the elections or, together, the majority? Certainly, the changes must bring something much more than that.

Despite this specific historical origin, which is situated in the process of adopting the Treaty that was intended to create a Constitution for Europe, it would be wrong to think, however, that the pivotal role allotted to the Parliament by Article 17.7 was the result of a unique impulse. Rather, the provisions of Article 17.7 represent a further step in the institutional development of the Union and, in particular, in the influence of the European Parliament on the appointment of the Commission in genera ${ }^{19}$. In

18 In that sense, see: Araceli Mangas Martín, "El nuevo equilibrio institucional en tiempos de excepción", Revista de Derecho Comunitario Europeo 50 (2015):24.

${ }_{19}$ In that regard, see: Building on the Spitzenkandidaten Model. Bolstering Europe's Democratic Dimension...": 2, accessed on 24 September 2020. See also: Westlake, "Chronicle of an Election Foretold:...": 24-40. In the same lines, see: Thomas Christiansen, "After the Spitzenkandidaten: fundamental change in the EU's political system?", West 
that respect, we should recall that, first, by the Maastricht Treaty, in 1992, it was stipulated that the appointment of the President and other Members of the Commission, by common accord of the governments of the Member States, would take place after approval by the European Parliament ${ }^{20}$. Second, thanks to the Treaty of Amsterdam, in 1997, the Parliament approved the candidate for President of the Commission, prior to the approval of the entire college of Commissioners ${ }^{21}$. Third, the Treaty of Nice in 2001 amended the appointment procedure in the European Council, moving from the need for unanimity to qualified majority ${ }^{22}$. Finally, via the Treaty of Lisbon, as we already know, the Parliament has gained more influence in the nomination ${ }^{23}$, on account of the necessity to link the nomination with the elections results. It rests for us to measure the scope of that influence.

\section{The "success" of the Spitzenkadidaten system in 2014. Empirical results}

The first occasion in which the citizens' voices should have been taken into account for the nomination of the Commission Presidency, after the entry into force of the Treaty of Lisbon, was the 2014 European Parliament elections, and the Parliament seized the opportunity.

Indeed, by a resolution of 22 November 2012 on the elections to the European Parliament in 2014, the European Parliament urged the European political parties "[... to nominate candidates for the Presidency of the

European Politics 39: 5 (2016): 994; Hilde Reiding; Fons Meijer, “ 'This time it's different' - the European lead candidate procedure of 2014 and its historical background", Parliaments, Estates \& Representation 39: 1 (2019): 64-79. Regarding the role of the Commission in the EU, see, among others: Marta Ortega Gómez, La Comisión Europea y el gobierno de la Unión (Madrid: Marcial Pons, 2013) and Fernando Castillo de la Torre, "La Comisión Europea y los cambios en el poder ejecutivo de la Unión Europea", Revista de Derecho Comunitario Europeo 50 (2015): 85-124.

${ }^{20}$ Article 158 of the Treaty establishing the European Economic Community, introduced by the Treaty on European Union, signed in Maastricht on 7 February 1992, OJ C191, 29 July 1992.

21 Amendment to Article 158 of the Treaty establishing the European Community introduced by the Treaty of Amsterdam amending the Treaty on European Union, the Treaties establishing the European Communities and certain related acts, OJ C340, 10 November 1997.

${ }^{22}$ Amendment to Article 214 of the Treaty establishing the European Community introduced by the Treaty of Nice, signed on 26 February 2001, OJ C325, 24 December 2002.

${ }_{23}$ On this issue see, for instance: Antonio Calonge Velázquez, "El Consejo Europeo y sus relaciones con las demás instituciones de la Unión", Revista de Derecho de la Unión Europea 18 (2010): 109-110. 
Commission $[\ldots]^{\prime 24}$, with the aim of enhancing the legitimacy of this institution. Thus, in the light of the wording of the resolution -elections to the European Parliament- and the call to European parties to nominate candidates for the Commission Presidency, there can be no doubt about the Parliament's conviction on the existence of an obligation to follow the result of the elections, deriving from Article 17.7 TEU. The Parliament added that it expected "[...] those candidates to play a leading role in the parliamentary electoral campaign, in particular by personally presenting their programme in all Member States of the Union" 25.

For its part, the Commission also seemed to share that conviction, when, on 12 March 2013, it called on European political parties to nominate candidates for the office of the Commission President ${ }^{26}$.

However, the European parties, which consist of various separate member parties at the national level, amalgamated into European party organizations, did not have any indication on how to proceed for that selection ${ }^{27}$. Thus, due to the fact that there are not so far European lists, even if there

${ }^{24}$ European Parliament resolution of 22 November 2012 on the elections to the European Parliament in 2014, P7_TA(2012)0462.

25 Ibid.

${ }^{26}$ Recommendation 2013/142/EU on enhancing the democratic and efficient conduct of the elections to the European Parliament of 12 March 2013 (OJ L 79, 21 March 2013).

${ }^{27}$ See on that respect: Gert-Jan Put; Steven Van Hecke; Corey Cunningham; Wouter Wolfs, "The Choice of Spitzenkandidaten: A Comparative Analysis of the Europarties' Selection Procedures", Politics and Governance 4: 1 (2016): 14. In this regard, there is no need to recall that the procedures for electing the European Parliament are governed both by European and national legislation. The European legislation, which defines rules common to all Member States, lay down general principles, like proportional representation, thresholds, incompatibilities, etc. This legislation is contained basically in the Act of 20 September 1976 concerning the election of the representatives of the Assembly by direct universal suffrage (1976 Electoral Act, 76/787/ECSC, EEC, Euratom: Decision of the representatives of the Member States meeting in the council relating to the Act concerning the election of the representatives of the Assembly by direct universal suffrage, $\boldsymbol{O J} \mathrm{L}$ 278, 8 October 1976), which has undergone several modifications. For instance, in 2002, through the 2002/772/ EC, Euratom: Council Decision of 25 June 2002 and 23 September 2002 amending the Act concerning the election of the representatives of the European Parliament by direct universal suffrage, annexed to Decision 76/787/ECSC, EEC, Euratom (OJ L 283, 21 October 2002). The last amendments to the 1976 Electoral Act were adopted by Council Decision (EU, Euratom) 2018/994 of 13 July 2018 amending the 1976 Electoral Act (Council Decision (EU, Euratom) 2018/994 of 13 July 2018 amending the Act concerning the election of the members of the European Parliament by direct universal suffrage, annexed to Council Decision 76/787/ECSC, EEC, Euratom of 20 September 1976 (OJ L 178, 16 July 2018). While national laws rule other important issues, such as the number of constituencies or the exact electoral system. About the impact of the new nomination procedure on the role of European parties, see: Oliver Höing; Johannes Müller Gómez, "Towards the German model? Spitzenkandidaten and European Elections 2014", Europe en formation: les cahiers du fédéralisme 373:3 (2014): 45-65. 
have been already several proposals in that line, the citizens cannot vote for the leader of the European party who should become President of the Commission, with the exception, of course, of the voters of her or his constituency ${ }^{28}$. In that case, the only solution was to proceed to internal elections in the European parties beforehand.

In that line, the EPP convened an Election Congress in March 2014 in Dublin, in which Jean-Claude Juncker was elected as the party candidate for President of the European Commission, obtaining a majority of votes against Michel Barnier ${ }^{29}$.

For its part, the Group of the Progressive Alliance of Socialists and Democrats in the European Parliament (S\&D) elected Martin Schulz as its common candidate for the 2014 European elections on the 1st of March 2014 during an election congress that took place in Rome ${ }^{30}$.

With regard to the Alliance of Liberals and Democrats for Europe Party (ALDE), two candidates raced for the selection, Olli Rehn and Guy Verhofstadt. Nevertheless, instead of convening an elective congress, they reached an agreement on 20 January 2014. The two candidates decided that Verhofstadt would be the ALDE Party's candidate for Commission President, while Olli Rehn would be the party's candidate for one of the other senior posts in the $\mathrm{EU}$, in particular in the field of economic affairs and foreign policy ${ }^{31}$.

28 After the 2014 elections, by Council Decision 2018/994, an interesting amendment has been introduced, calling on Member States to allow for the display, on ballot papers, of the name or logo of the European political party to which the national political party or individual candidate is affiliated. See Article 3b Council Decision (EU, Euratom) 2018/994 of 13 July 2018 amending the Act concerning the election of the members of the European Parliament by direct universal suffrage, annexed to Council Decision 76/787/ECSC, EEC, Euratom of 20 September 1976 (OJ L 178, 16 July 2018).

${ }^{29}$ See the press release: "Jean-Claude Juncker elected as EPP candidate for President of the European Commission", Dublin 7 March 2014, accessed on 28 September 2020, http:// juncker.epp.eu/press-releases/jean-claude-juncker-elected-epp-candidate-president-europeancommission.

30 See the press release: "Rome 2014. First PES Common Candidate: Martin Schulz", accessed on 28 September 2020, https://www.pes.eu/en/about-us/the-party/congress/rome2014/index.html.

${ }^{31}$ See the press release: "Agreement between Olli Rehn and Guy Verhofstadt - statement by ALDE party president", 20th January 2014, accessed on 10 November 2020, https://www. eureporter.co/frontpage/2014/01/21/agreement-reached-between-olli-rehn-and-guy-verhofstadt-statement-by-alde-party-president/?_cf_chl_jschl_tk__=e2ed95745ef57561a058456 750f7a93071405ea6-1605027541-0-AX66K71sCfSsH5m06vGGYlENxR6wEtbBC6DAksboAXHG4t1 vkgdG4acSfaM7oBnkcbU1Omr0jxAHAzs5iakLw2hfrhICeTD9Q31zI4JEKE2oIePQwfHirSxqax-xJI9526Z6Ut2Q7-P9fRelLG0VqqCNEheqkyRkkgPyPWiyAUJ8riFXOGUPCAWn2dfw7uQYkRZ5Wy8h28qk4bum4Fx5tL6nFXZE08XA5_PHd6dvBRL7Ga9bKpdU1KBJ1eXJDVjOSMxdcjXhgf2XwH4gnDXgX1cZDH8undhMEqIzc63Be5WOziKR1rNvLm05DM9BRqHEmVZ0PgsHOMdBNwwCk5fIy6VRfAgeilgyW51FLUHd0_iGhx5gWIDvOqHPp4S3CYSd9TxoF7PzB2JIvGkkJGmzpFs-cl-_damURWJZnuf7Arov 
When it comes to the Party of the European Left, it held its 4th Congress in Madrid under the name "Change Europe. For a Europe of Work" in December 2013. One of the issued to be decided was the party candidate for the Presidency of the Commission in the subsequent European elections. In the end, a majority of the delegates gave their support to Alexis Tsipras' candidature ${ }^{32}$.

More innovative still, the European Greens party organized a Europewide open online process to select their leading candidates for the European elections and then the President of the Commission. That process, called "Green Primary", ended up in January 2014 by selecting Ska Keller and José Bové as their party's nominees ${ }^{33}$.

Once all the main political parties had decided their candidatures, for the first time since there are direct elections to the European Parliament, they launched an EU-wide election campaigns and held public events across the Union to raise awareness of their candidates and their political programmes for the future of the EU. Thus, instead of campaigning only in the territory of their constituencies, the lead candidates travelled around the Continent to obtain popular support ${ }^{34}$ - although in reality it seems that they only visited a few countries selected on the basis of various parameters $^{35}$-. On top of that, some televised debates were organized among the Spitzenkandidaten in different Member States and languages ${ }^{36}$. In so doing, the awareness among the population about the personalities of the main candidates and the problems at stake during the subsequent elections could have been higher than in previous occasions, in the attempt to revert the so-

${ }^{32}$ In this regard, see the press release: "Tsipras, Nominated by the European Left, as the Voice to Denounce the Policies of the Troika in the European Commission". Accessed on 28 September 2021, https://oldsite.european-left.org/de/4th-el-congress/tsipras-nominated-european-left-voice-denounce-policies-troika-european-commission.

${ }^{33}$ On this point, see the press release: "Ska Keller and José Bové will lead the Greens in their European campaign", European Greens, 29th January 2014, accessed on 10 November 2020, https://europeangreens.eu/press-release-jose-bove-and-ska-keller-will-lead-greenstheir-european-campaign.

34 Apparently, they visited only 246 cities. See in this regard: "Report on the 2014 European Parliament elections", Communication from the Commission to the European Parliament, the Council, the European Economic and Social Committee and the Committee of the Regions: 7.

${ }^{35}$ In that sense, see: Johannes Müller Gómez; Wolfgang Wessels, "The EP Elections 2014 and their Consequences. A Further Step towards EU Parliamentarism?", Cuadernos Europeos de Deusto 52 (2015): 41.

${ }^{36}$ See: "Report on the 2014 European Parliament elections", Communication from the Commission to the European Parliament, the Council, the European Economic and Social Committee and the Committee of the Regions, $\operatorname{COM(2015)} 206$ final: 6-7. In that regard, see also: Christiansen, “After the Spitzenkandidaten: fundamental change...”: 995-998. 
called second-order theory of the European elections ${ }^{37}$. According to this theory, most electors - and the political parties themselves - consider the European political arena to be less important than the national one and that they, accordingly, use their votes in EP elections to express approval or disapproval in respect of their national parties.

The elections to the European Parliament took place from 22 to 25 May 2014 in all the Member States of the Union, with a turnout of 42,61 $\%$, which suppose a small decrease with regard to previous one of 2009 $-42,97 \%$-. As a reminder, we should mention that the EPP won the elections, with the $29,43 \%$ of the vote cast and obtaining 221 seats. In second position, the S\&D secured the $25,43 \%$ of the votes and gained 191 seats. The third party in number of votes was the European Conservatives and Reformists, that obtained the $9,32 \%$ of vote cast, which represented 70 seats in the Parliament. Next to that, ALDE ranked fourth in the elections, with the $8,92 \%$ of the voters and 67 MEPs. The fifth party was the European United Left/Nordic Green Left, which obtained the $6,92 \%$ of the votes and 52 seats. Very close to the European United Left/Nordic Green Left, but behind, the European Greens were only be the sixth party in the elections, with a result of the $6,66 \%$ of voters and $50 \mathrm{MEPs}^{38}$.

After the elections, on 27 June 2014, the European Council nominated Jean-Claude Juncker, the head of the EPP, in a formal vote in which he obtained 26 votes in favour meanwhile David Cameron, the British Prime Minister $^{39}$ and Viktor Orbán, the Hungarian Prime Minister, voted against his candidacy ${ }^{40}$. Then, on 15 July 2014, the European Parliament, by a large majority of votes - 422 in favour, 250 against, 47 abstention -, elected Juncker as President of the Commission ${ }^{41}$. Some weeks later, once Juncker and the Member States had agreed on the formation of the College of Com-

37 On this point see: Karlheinz Reif; Hermann Schmitt, "Nine second-order national elections- a conceptual framework for the analysis of European elections results", European Journal of Political Research 8:1 (1980): 3-44. See also: Arregui, "Problemas de legitimidad democrática...": 94.

38 See: European Parliament, "Results of the 2014 European elections", accessed on 30 September 2020, https://www .europarl.europa.eu/elections2014-results/en/electionresults-2014.html.

39 David Cameron, among other things, opposed the nomination of Jean-Claude Juncker on the grounds that he was too federalist, see: House of Commons Library, "European Parliament Elections 2014", Research paper 14/32, 11 June 2014: 7.

40 European Council, the President, Press release: "Remarks by President Herman Van Rompuy following the European Council”, 27 June 2014, accessed on 1 October 2020, https://data.consilium.europa.eu/doc/document/ST-138-2014-INIT/en/pdf.

41 European Parliament, Press release, "Parliament elects Jean-Claude Juncker as Commission President", accessed on 1 October 2020, https://www.europarl.europa.eu/news/en/ press-room/20140714IPR52341/parliament-elects-jean-claude-juncker-as-commission-president. 
missaries at the 5 September 2014 meeting of the Council of the European Union, the European Parliament, on 22 October 2014, gave its strong support to the new European Commission with 423 votes in favour, 209 against and 67 abstentions $^{42}$. Finally, the European Council appointed the new European Commission at its Summit of 23-24 October 201443.

Therefore, for the first time in history, the Member States appointed the leader of the party that had won the elections to the European Parliament as the President of the Commission, putting into practice the changes brought about by Article 17.7 TEU ${ }^{44}$.

Even more, they were achieved both aims of the interpretation of Article 17.7 TEU that the Parliament wanted to imposed through the Spitzenkandidaten system, that it's to increase the power of Parliament in the context of institutional balance as well as the weight of citizens' opinion. First, with regard to the extension of Parliament's power, some analyst, such as Thomas Christiansen, pointed out that the introduction of the Spitzenkandidaten system has led to a greater parliamentarisation of the Union, a greater politicisation of the European Commission and a greater union between Parliament and the Commission ${ }^{45}$. Second, in relation to the popular support, if we give credit to a survey commissioned by the European Parliament after the 2014 elections, it seems that a majority of European citizens cheered the role that the European Parliament played in Juncker's election ${ }^{46}$.

However, despite the overall positive impression given by the implementation of the changes linked to the new Article 17.7 TEU, two relevant nuances must be taken into account. On the one hand, the slight

${ }^{42}$ European Parliament, Press release, 22 October 2014, "European Parliament elects Juncker Commission", accessed on 1 October 2020, https://ec.europa.eu/commission/ presscorner/detail/en/IP_14_1192.

${ }^{43}$ See: European Council (23 and 24 October 2014), “Conclusions”, EUCO 169/14, 24 October 2014.

${ }^{44}$ As for its practical application in 2014, according to analysts, it should be noted that in addition to the influence of the EPP on the origin of the idea, which we noted above, when it was implemented in reality, much is due to the figure of Martin Schulz, who worked resolutely to achieve this objective. In that sense, see: Joseph Weiler, "The Spitzenkandidaten Exercise One Year Later - The Unsung Hero", European Journal of International Law 26: 2 (2015): 312: See also: Reiding; Meijer, “'This time it's different' - the European lead candidate procedure...": 78.

${ }^{45}$ Christiansen, "After the Spitzenkandidaten..." :1005. See also: Simon Hix, "Why the EU needs (Left-Right) Politics? Policy Reform and Accountability are Impossible without it", in Stefano Bartolini; Simon Hix, "Politics: The Right or the Wrong Sort of Medicine for the EU?", Notre Europe Policy Paper 19 (2006): 7-11.

${ }^{46}$ See: European Parliament, 2014, "Parlameter survey 2014: citizens cheer Parliament's role in Juncker election", accessed on 30 September 2020, http:// www.europarl.europa.eu/news/ en/press-room/20150213IPR24006/ parlameter-survey-2014-citizens-cheer-parliament-s-roleinjuncker-election. 
decrease of the turnout - the $42,61 \%$ of the vote cast - in comparison to the 2009 elections. On the other hand, according to above mentioned survey, only the $5 \%$ of the respondent indicated that the main reason that made them going to vote was to influence the choice of Commission President ${ }^{47}$, so that imply that the changes operated by Article 17.7 TEU had only little impact in the turnout. In my opinion, it also implies that the above mentioned results regarding the satisfaction of the voters in relation to the role of the Parliament were not completely linked to the Spitzenkandidaten system, if we want to give any credit to the survey commissioned by the European Parliament. Or perhaps, the question was not correctly put forward.

In any event, only the future could say then if that steps were to be maintained in subsequent elections ${ }^{48}$. We will see what happened in the 2019 elections further.

\section{The fall of the Spitzenkandidaten system: toward a more (un) sustainable democracy in the EU?}

\section{The tension between the European Parliament and the European}

Council with regard to the Spitzenkandidaten system. Theoretical and power disputes

In the presence of Juncker's appointment in 2014 - the head of the party winner of the elections - by all the main actors in the Union's politics, it can be argued that Members States, along with the Council and the European Council, had lost a battle in favour of the European Parliament and the democratisation of the EU. However, the war was still going on, of course...

The Parliament was strongly in favour of following this practice, and proposed it vehemently for the following elections. Already in November 2015, the European Parliament took the first step when it adopted a resolution on the reform of the 1976 Electoral Act in the context of the special legislative procedure laid down in Article 223 TFEU. The resolution aimed at strengthening the democratic and transnational dimension of the elections to the European Parliament, by proposing several innovations, such as equal

47 See: European Parliament, 2014 post-election survey: 25, accessed on 30 September 2020, http://www.europarl.europa.eu/pdf/eurobarometre/2014/post/post_2014_survey_ analitical_overview_en.pdf

48 On this point see, for instance: Marco Goldoni, "Politicising EU Lawmaking? The Spitzenkandidaten Experiment as a Cautionary Tale", European Law Journal 22: 3 (2016): 279-295. 
visibility of European and national political parties on ballot papers, or of a joint constituency in which lists are headed by each European party's candidate for the post of President of the Commission ${ }^{49}$.

Furthermore, in its Decision of 7 February 2018 on the Revision of the Framework Agreement on relations between the European Parliament and the European Commission, it stated that the Head of List system contributes to transparency, "[...] as candidates for President of the Commission are made known prior to the European elections, rather than after them as was previously the case" ${ }^{50}$. For the European Parliament, moreover, the procedure for appointing heads of list " $[\ldots]$ fosters the political awareness of European citizens in the run-up to the European elections and reinforces the political legitimacy of both Parliament and the Commission by connecting their respective elections more directly to the choice of the voters; $[\ldots]$ ". 51 . In addition, the European Parliament considered "[...] that in 2014 the 'Spitzenkandidaten' process proved to be a success, and stresses that the 2019 European elections will be the occasion to cement the use of that practice; [...]" 52 .

On top of that, the Parliament made a veiled threat to the European Council by clearly stating that: "[...] by not adhering to the 'Spitzenkandidaten' process, the European Council would also risk submitting for Parliament's approval a candidate for President of the Commission who will not have a sufficient parliamentary majority" 53 . The Parliament also warned the European Council, with no less clarity, that it was ready " $[\ldots]$ to reject any candidate in the investiture procedure of the President of the Commission who was not appointed as a 'Spitzenkandidat' in the run-up to the European elections" ${ }^{24}$.

49 European Parliament Resolution of 11 November 2015 on the reform of the electoral law of the European Union (2015/2035(INL)), OJ C 366, 27 October 2017. We have to recall that the legal basis for reforming the electoral procedure is enshrined in Article 223 TFEU. Article 223.1 TFEU established that the "[...] European Parliament shall draw up a proposal to lay down the provisions necessary for the election of its Members by direct universal suffrage" and that the Council, "[...] acting unanimously in accordance with a special legislative procedure and after obtaining the consent of the European Parliament, which shall act by a majority of its component Members, shall lay down the necessary provisions. These provisions shall enter into force following their approval by the Member States in accordance with their respective constitutional requirements".

${ }^{50}$ European Parliament decision of 7 February 2018 on the revision of the Framework Agreement on relations between the European Parliament and the European Commission (2017/2233(ACI)): (5).

${ }^{51}$ Ibid. : (6).

52 Ibid. : (9).

53 Ibid. : (3).

54 Ibid. : (4). 
By contrast, the European Council clearly expressed its reluctance to accept the system of the head of list. Therefore, in an informal meeting that took place on February 2018, the heads of State or Prime Ministers of the Member States stressed that the formulation of Article 17.7 TEU, “[...] means that the European Council cannot deprive itself of its prerogative to choose the person it proposes as President of the European Commission without a change of the Treaty $[\ldots]^{\prime 55}$. For the Heads of State or Government, the process of appointing heads of list is linked to the question of "balances" in the context of high-level appointments, such as respecting the geographical and demographic diversity of the Union and its Member States, or sex balance."[...] If the President of the Commission were to be selected in accordance with the logic of the 'Spitzenkandidaten' process, and if such balances are to be taken into account, the choice of the European Council regarding other nominations will be more limited." 56.

In addition, a few months later, according to the special legislative procedure settled down by Article 223.1 TFEU, the Council of the European Union, adopted unanimously, on 7 June 2018, a draft decision on the reform of the Electoral Act. In that document, the Council reiterated its refusal to the establishment of both the system of the heads of list or the joint constituency, as was suggested by Parliament in November 2015, but accepted the Parliament suggestion in order to have the name of the European parties on ballot papers ${ }^{57}$. On 4 July 2018, the European Parliament gave its consent ${ }^{58}$ and consequently the Act was adopted by the Council on 13 July $2018^{59}$.

The Commission, for its part, was also in favour of repeating the Spitzenkandidaten system for the 2019 elections. For example, by its Recommendation 2018/234 of 14 February 2018, the Commission called on each European political party to make known, in good time before the

55 European Council, Leaders' Agenda, February 2018, The next institutional cycle, High-level appointments.

56 Ibid.

57 Council of the European Union, Proposal for a Council Decision adopting the provisions amending the Act concerning the election of the members of the European Parliament by direct universal suffrage (the 'Electoral Act'), 9425/18.

58 European Parliament legislative resolution of 4 July 2018 on the draft Council decision amending the Act concerning the election of the members of the European Parliament by direct universal suffrage, annexed to Council Decision 76/787/ECSC, EEC, Euratom of 20 September 1976 (09425/2018 - C8-0276/2018 - 2015/0907(APP)), (OJ C 118, 8 April 2020).

59 Council Decision (EU, Euratom) 2018/994 of 13 July 2018 amending the Act concerning the election of the members of the European Parliament by direct universal suffrage, annexed to Council Decision 76/787/ECSC, EEC, Euratom of 20 September 1976 (OJ L 178, 16 July 2018). 
elections to the European Parliament and if possible by the end of 2018, the candidate for the office of President of the European Commission whom it supports and, as far as possible, the political programme of that candidate ${ }^{60}$. According to the Commission, "[r]einforcing the democratic legitimacy of the EU and ensuring the participation of citizens in the political life at European level is essential" 61 . It also insisted on the benefits of having recourse to the Spitzenkandidaten system for the improvement of the elections turnout. For the Commission, European citizens would be readier to vote in the elections to the European Parliament "[...] if they would trust that they can have their say on the Union's most important choices, such as the selection of the leaders of the EU institutions and the establishment of priorities for the future of the Union" 62 .

To put an end to the presentation of this institutional quarrel, it should be highlighted that, at least for us, this reference to the "trust" of the citizens is capital. Even if in 2014, probably because it was the first time, citizen's awareness about the fact that they can influence the President of the Commission choice with their vote was not high, the seed was thrown, and over time it would bear fruit, if the European institutions keep their promises. One cannot play with people's trust, and even less in the fragile context of European politics.

\section{The abandonment of the Spitzenkandidaten system in 2019. Empirical results of the disputes}

After having presented the chain of events that surrounded the 2014 elections, we will shed light on what happened before and after the 2019 ones.

On the one hand, it should be underlined that, irrespective of the dispute that we have presented in the previous section between the European institutions, a large proportion of citizens cherished the Spitzenkandidaten system as an ally in the fight for democracy within the EU. Indeed, as a Eurobarometer survey that the European Parliament presented in 2018 shows, one year before the elections, almost half (49\%) of the 27 Member States citizens considered that having recourse for the second time to the head of the list process would increase their likelihood to

${ }^{60}$ See: Commission Recommendation (EU) 2018/234 of 14 February 2018 on enhancing the European nature and efficient conduct of the 2019 elections to the European Parliament, $O J$ L 45, 17 February 2018.

61 Ibid:: (5).

62 Ibid. 
vote. By contrast, $43 \%$ of respondents sustained that the Spytzenkandidaten process would not affect their decision to vote, while $8 \%$ of citizens declared that they did not know whether that element would have a positive or a negative impact on their motivation to vote ${ }^{63}$. On the other hand, most respondents $(63 \%)$ agreed that the lead candidate system had brought about more transparency in European politics, supposes a significant progress for European democracy (61\%) and increases the European Commission legitimacy $(60 \%)^{64}$.

Besides, the electoral machinery began to function as if the winner in the elections would be the President of the Commission. In fact, the parties began to choose their candidates for the 2019 elections at the end of 2018 . Thus, for example, the EPP, at a congress in Helsinki on 8 November 2018, elected Manfred Weber ${ }^{65}$. For its part, the S\&D decided on its candidate, Frans Timmermans, the then First Vice-President of the Commission, at a congress in Lisbon on 8 December $2018^{66}$. On 12 November 2018, the European Conservatives and Reformists chose Jan Zahradil as their Spitzenkandidat ${ }^{67}$. ALDE followed another path; during a party congress that took place in Madrid, on 9 November 2018, the party announced that, instead of nominating one lead candidate, it would designate a team of liberal leaders for the upcoming elections ${ }^{68}$. The European Green Party, at its 23-25 November 2018 Berlin Congress, elected Ska Keller - who had been also one of its candidates for the 2014 election - and Bas Eickhout as their Spitzenkandidaten ${ }^{69}$. To complete the

${ }^{63}$ European Parliament, "Democracy on the move European Elections. One year to go, Eurobarometer Survey 89.2 of the European Parliament. A Public Opinion Monitoring Study": 30. Accessed on 26 October 2020, https://www .europarl.europa.eu/at-your-service/ files/be-heard/eurobarometer/2018/eurobarometer-2018-democracy-on-the-move/report/enone-year-before-2019-eurobarometer-report.pdf.

64 Ibid: 7.

${ }^{65}$ In this regard, see the EPP press release: "Manfred Weber elected as EPP candidate for the President of the European Commission", accessed on 5 October 2020, https://www. epp.eu/press-releases/manfred-weber-elected-as-epp-candidate-for-the-president-of-theeuropean-commission/.

${ }_{66}$ On this point, see the European Socialist's Party press release: "Frans Timmermans launches campaign to become President of the European Commission in Lisbon", accessed on 5 October 2020, https://www.pes.eu/en/news-events/news/detail/Frans-Timmermanslaunches-campaign-to-become-President-of-the-European-Commission-in-Lisbon/.

${ }^{67}$ See the press release: "Conservatives endorse Czech MEP for Commission top job", accessed on 5 October 2020, https://www.politico.eu/article/tories-european-allies-endorsejan-zahradil-for-commission-top-job/.

${ }^{68}$ See the press release: "Towards the 2019 Elections", accessed on 5 October 2020, https://www.aldeparty.eu/towards_2019_elections.

${ }^{69}$ See the press release: "European Greens elect leading duo", accessed on 5 October 2020, https://europeangreens.eu/news/european-greens-elect-leading-duo. 
list of the candidates of the larger parties, we must point out that, at the beginning of the elections' year, on 26-27 January 2019, at the meeting of the Executive Board of the Party of the European Left Party, Violeta Tomič and Nico Cue were designated as its lead candidates ${ }^{70}$.

With regard to the election campaign, it should be noted that, according to a report published in July 2019 containing the results of an EU-funded research project (Platform Europe) on the election campaign and conducted by a network of universities, led by the Italian Roma Tre, it could not be considered a true supranational campaign. It was more a question of the overlapping of different national campaigns, with a prevalence of national content over European one. In addition, it is remarkable that the Spitzenkandidaten factor could not alter this trend, as it had little communication potential. In fact, as this study shows, only some of the lead candidates made a real European tour ${ }^{71}$, to which we must add the fact that several parties did not even appoint their spitzenkandidaten or, as ALDE did, limited themselves to appointing a team of politicians to this role ${ }^{72}$. Therefore, the findings of this study would go along the lines of the so-called second-order theory of the European elections ${ }^{73}$.

As for the elections, that took place between 23 and 26 May 2020, they were marked mainly by the last hour participation of the UK, embroiled in its parliamentarian process to exit the EU. In connection with the results, it should be emphasized that, like in 2014, the EPP won the elections with the $20.80 \%$ of the vote cast, obtaining 182 seats, which supposed a significant decrease in comparison with the 2014 results. In second position, the S\&D attained the $17.88 \%$ of the vote, gaining 154 seats, also far away from its previous results. The combination of those losses implied that both parties had lost the absolute majority that hitherto they have mustered. The third party in contention was ALDE, that on 12 June 2019 decided to be renamed

${ }^{70}$ See the press release: "Two candidates from the people for the people", accessed on 5 October 2020, https://www.european-left.org/campaigns/two-candidates-from-the-peoplefor-the-people/.

71 As we have already noted, something similar happened in the case of the 2014 campaign, see in that sense: Müller Gómez; Wessels, "The EP Elections 2014 and their Consequences...": 41.

72 Edoardo Novelli; Bengt Johansson (eds.), “2019 European Elections Campaign. Images, topics, media in the 28 Member States. International research project lead by University Roma Tre Funded by the European Parliament Category Events COMM/ SUBV/2018/E/0147 Directorate-General for Communication Public Opinion Monitoring Unit July 2019": 15, accessed on 27 October 2020, https://www.electionsmonitoringcenter. eu/article/b8948aed-67b6-4575-bb9c-4df29ae08538.

73 See: Reif; Schmitt, "Nine second-order national elections...": 3-44. 
as Renew Europe ${ }^{74}$, with the $12.01 \%$ of the vote cast and 108 MP's. For its part, the group of the Greens/European Free Alliance was voted by the $10.04 \%$ of the voters and secured 74 seats, and close to them, Identity and Democracy group obtained 73 seats derived from the $10.59 \%$ of the vote cast $^{75}$.

However, the most relevant aspect in relation to the 2019 European Parliament elections was neither the participation of the UK nor the results, but the turnout. The fact is that, for the first time in history, the downward trend in the percentage of participation was reversed, since in May 2019 more than half of the potential voters $(50.66 \%)$ voted, the highest percentage in 20 years. In fact, the participation in the elections had fallen from $61.99 \%$ in 1979 to $42.61 \%$ in 2014 , despite the use of the Spitzenkandidaten system in this last one, as we know ${ }^{76}$.

In addition, it seems clear that these positive results in terms of voting percentages in the 2019 elections, were accompanied by a positive perception of the growing importance of the voice of citizens in the political functioning of the Union. Indeed, the results of the Eurobarometer that contains the post-electoral survey, which field-work took place in June 2019, that is before the nomination of the President of the Commission, shows that more than half of Europeans (56\%) considered that their voice counted in the Union ${ }^{77}$. Besides, according to the same Eurobarometer, there is a clear connection between thinking that one's voice counts in the EU and voting in the European Parliament elections ${ }^{78}$.

In this context, taking into account the results of the elections, and notwithstanding the slightness of the EPP victory, it is obvious that Manfred Weber should have been appointed as President of the Commission, according to the Spitzenkandidaten system. However, the reality was another... In fact, already on 28 May 2019, two days after the elections, with the occasion of an informal dinner of EU Heads of State or Government, the President of the European Council put forward again the

${ }^{74}$ See the press release: "ALDE Group becomes Renew Europe", accessed on 20 October 2020, https://www.aldeparty.eu/alde_group_becomes_renew_europe.

75 See all the results: European Parliament, "2019 European election results", accessed on 26 October 2020, https://www.europarl.europa.eu/election-results-2019/en/europeanresults/2019-2024/

76 Ibid.

77 See: "The 2019 post-electoral survey. Have European elections entered a new dimension. Eurobarometer Survey 91.5 of the European Parliament A Public Opinion Monitoring Study": 11. Accessed on 26 October 2020, https://www.europarl.europa.eu/atyour-service/files/be-heard/eurobarometer/2019/post-election-survey-2019-complete-results/ report/en-post-election-survey-2019-report.pdf.

78 Ibid. 
well-known position of the Member States. According to him, there cannot be automaticity when it comes to elect the Commission President. For President Tusk, in accordance with the Treaties, "[...] the European Council should propose, and the European Parliament should elect"79. He ended up by recalling that, before taking such a decision, balances should be taken into account, "[...] that is: the need to reflect the diversity of the Union when it comes to geography, the size of countries, gender as well as political affiliation" 80 . In the end, after some intense discussions about the core of top EU positions nomination, on 2 July 2019, the European Council came up with the decision proposing Ursula von der Leyen to the European Parliament as candidate for President of the European Commission ${ }^{81}$. At that time, she was serving as German Minister of Defence. For its part, the European Parliament elected the proposed candidate on 16 July $2019^{82}$, by a majority of 383 votes in favour, 327 against, and 22 abstentions ${ }^{83}$. Then, after a new elaborate process, on 27 November 2019 the European Parliament gave its consent to the appointment, as a body, of the President, the High Representative of the Union for Foreign Affairs and Security Policy, and the other members of the Commission ${ }^{84}$. Finally, on 28 November, the European Council appointed by written procedure the new Commission for the next term of office ${ }^{85}$. By so doing, it became evident that this time the Spitzenkandidaten doctrine was not followed. Moreover, reality also demonstrated that the Parliament's menace, according to which it would not elect a non Spitzenkandidaten, was not put into practice.

In short, it seems that this abandonment of the head-of-list system is yet another episode in the struggle for institutional balance between

79 See the press release: European Council, "Remarks by President Donald Tusk at the press conference of the informal dinner of EU heads of state or government", accessed on 27 October 2020, https://www.consilium.europa.eu/en/press/press-releases/2019/05/28/remarksby-president-donald-tusk-at-the-press-conference-of-the-informal-summit-of-eu-heads-ofstate-or-government/.

80 Ibid.

${ }^{81}$ European Council Decision (EU) 2019/1136 of 2 July 2019 proposing to the European Parliament a candidate for President of the European Commission, OJ L 179, 3 July 2019.

${ }^{82}$ European Parliament decision of 16 July 2019 on the election of the President of the Commission (2019/2041(INS)).

${ }^{83}$ See the press release: European Parliament, "Parliament elects Ursula von der Leyen as first female Commission President", 26 July 2019, accessed on 11 November 2020, https://www .europarl.europa.eu/news/en/hearings2019/commission-president2019/20190711IPR56824/parliament-elects-ursula-von-der-leyen-as-first-femalecommission-president.

${ }^{84}$ European Parliament decision of 27 November 2019 electing the Commission (2019/2109(INS)).

${ }^{85}$ European Council Decision (EU) 2019/1989 of 28 November 2019 appointing the European Commission, OJ L 308, 29 November 2019. 
intergovernmental and parliamentary elements, present from the beginning of European integration.

Nevertheless, whatever the reasons were, the institutions of the EU have not respected the voice of the European citizens, even when the electorate went to vote thinking that they were choosing the President of the Commission ${ }^{86}$.

\section{Conclusions}

In the process of the parliamentarisation of the EU, the Treaty of Lisbon took a further step forward by introducing into the founding treaties - Article 17.7 TEU - the need to take into account the elections to the European Parliament for the appointment of the President of the Commission. Nevertheless, the European Parliament has been trying to impose its interpretation of Article 17.7 TEU, which has been coined into the Spitzenkandidaten doctrine, according to which the head of the party winning the elections should be elected as Commission President. Such an interpretation amounts to depriving the European Council of any capacity to decide.

For us, notwithstanding the lack of clarity in the above mentioned phrase wording, its interpretation cannot alter the meaning of the other provisions of Article 17.7 TEU, which establish that it is up to the European Council to propose the candidate and up to the Parliament to elect him/her. The Treaty seems to give the Council the upper hand in the process. However, one should not think of an absolute preponderance, as this is very limited by several factors: firstly, because Parliament can of course veto the European Council's proposal and given that, in the light of all the provisions governing the process of electing both the President and the Commission as a whole, that process must be conducted in a spirit of dialogue between the two institutions. And secondly, and above all, because, although there is no need to recall it, in the end Parliament keeps the ace of the motion to censure the Commission up its sleeve, under Article 17. 8 TEU and in accordance with Article 234 TFEU. Thus, while its role in the election of the President of the Commission is somewhat

${ }^{86}$ For Stergios Fotopoulos, tha abandonment of the Spitzenkandidaten process, "[...] was a step backwards, in the direction of a less transparent and less inclusive decisionmaking process made behind closed doors, and the inter-institutional quarrel over the issue was perceived by some Eurosceptics as 'another EU weakness". See: Stergios Fotopoulos, "What sort of changes did the Spitzenkandidat process bring to the quality of the EU's democracy?", European View 18: 2 (2019): 200. 
more secondary than that of the European Council, in the overall relationship with the Commission, Parliament plays the primary role ${ }^{87}$.

Therefore, although the TEU requires the results of the European Parliament elections to be taken into account, nothing in the treaties imposes the automatism that the leader of the most voted party will imperatively be the President of the Commission. Perhaps the European Parliament has gone too far in trying to impose this automatism on the occasion of the 2014 and 2019 elections. By not proposing Manfred Weber, the leader of the most voted party in the 2019 elections, as a candidate, the European Council has prevented the consolidation of the 2014 precedent. In this sense, although the Parliament may again consider the forthcoming elections as a direct means of electing the President of the Commission, and thus impose its interpretation of Article 17.7 TEU, the most effective way of ensuring this objective would be to reform the Treaty ${ }^{88}$.

However, nobody should feel that this step must be taken necessarily, as the EU, being an international organisation and not a state, should not mimetically follow the state political model ${ }^{89}$. Although it may have its advantages, as we shall see below, it is not imperative that the President of the Commission should be elected by the European Parliament, without the EU being blamed for a loss of democratic character.

In addition to this new step in parliamentarisation, which is mentioned above, the text of Article 17.7 of the TEU also expresses the desire to bring the European elections closer to the citizens, so that their opinion is taken into account when the President of the Commission is elected. The aim was to halt the historic decline in participation in parliamentary elections since 1979. And it seems that both the results of participation in 2019 and the perception of the voters show that Parliament's interpretation of article 17.7 TEU according of the Spitzenkandidaten system has been useful in reversing the aforementioned trend. European citizens have finally been

87 As for the history of interinstitutional relations between the European Parliament and the Commission, see, for instance: European Parliament, "Building Parliament: 50 years of European Parliament History,1958-2008" (2009): 184-207. See specially the cases of the Santer's Commission or the Prodi's Commission.

${ }^{88}$ In that sense, see also: Manuel Müller, "Make European Elections more meaningful. How to Reinforce Parliamentary Democracy at the EU Level" (Brussels: FriedrichEbert-Stiftung, 2020), 4, accessed on 3 November 2020, http://iep-berlin.de/wp-content/ uploads/2020/07/Make-european-elections-more-meaningful_Mueller.pdf. On balanced interinstitutional relations and their translation into the treaties, see: Paul Craig, "Institutions, Power and Institutional Balance", in The Evolution of EU Law (eds.) Paul Craig; Grainne de Burca (Oxford: Oxford University Press, 2011), 41-84.

${ }^{89}$ In that sense, see also: Mangas Martín, "El nuevo equilibrio institucional en tiempos de excepción...": 25. 
attracted by elections that have traditionally been considered second rate to national ones, and have thus been able to feel closer to the political life of the EU. There is no doubt that, from this point of view, the head-of-list system does represent a major advance in terms of the public's perception of the EU's legitimacy, contributing significantly to its sustainability.

In any event, I consider that the fact that citizens voted in the 2019 elections to the European Parliament in the belief that their votes would be decisive in appointing the President of the Commission and, in the end, it was not elected an Spitzenkandidaten as head of the Commission, is a very serious lack of consideration for citizens. European citizens have once again felt their trust betrayed by the European institutions. The European Council, the Commission and the Parliament should have agreed before letting the citizens be betrayed.

It is not clear what will happen in the next elections, but it would be unforgivable if, whether or not the Spitzenkandidaten system is continued, with whatever modifications, citizens are once again betrayed. In my view, another setback of this kind would make democracy in the EU unsustainable.

\section{About the author}

Professor Espaliú got a scholarship from the Spanish Ministry of Education (1995-1998), he has been Lecturer in the University of Navarre (Spain) (1998-2000), Legal Officer of the International Court of Justice (2000-2006) and Ramón y Cajal Researcher in the University of Córdoba (Spain) (2007-2012), Professor, Vice-Dean of the Faculty of Law and Director of the Charlemagne Institute of European Studies at the International University of Catalonia (2012-2018). At present, he is Professor in Public International Law and European Union Law, as well as Principal Investigator/Full Professor of the Research Group about Security, Risks Management and Conflicts of Nebrija University, Madrid (Spain). He obtained the accreditation as Associate Professor (ANECA) in 2011 and as Full Professor (AQU) in 2015. Furthermore, he has been awarded two sixyears research periods (CNAI) and two six-years research periods (AQU). Regarding European Citizenship, he has published, among others, the following articles: A Reflection on the Participation of Individuals in the Creation of European Law through the European Citizens' Initiative and its Scope in International Law, Cuadernos Europeos de Deusto, N. . 54, 2016, pp. 181-202; Fostering the Participation of Citizens as a Factor of Legitimacy in the European Integration Project, Cuadernos Europeos de Deusto, N. ${ }^{\circ}$ 60/2019, pp. 157-185. 


\section{Sobre el autor}

El profesor Espaliú ha sido becario de investigación de Ministerio de Educación (1995-1998), profesor de la Universidad de Navarra (19982000), Letrado de la Corte Internacional de Justicia (2000-2006), investigador Ramón y Cajal en la Universidad de Córdoba (2007-2012) y profesor, vicedecano de la Facultad de Derecho y Director del Instituto Carlomagno de Estudios Europeos en la Universitat Internacional de Catalunya (2012-2018). En la actualidad, es profesor de Derecho Internacional Público y de la Unión Europea, así como Investigador Principal/Catedrático del Grupo de Seguridad, Gestión de Riesgos y Conflictos en la Universidad Nebrija de Madrid. Ha obtenido la acreditación de profesor titular de ANECA en 2011 y la acreditación de catedrático de la AQU en 2015. También cuenta con dos sexenios de investigación del CNAI y dos sexenios de investigación de AQU. En materia de ciudadanía europea, entre otros trabajos, ha publicado: A Reflection on the Participation of Individuals in the Creation of European Law through the European Citizens' Initiative and its Scope in International Law, Cuadernos Europeos de Deusto, N. ${ }^{\circ}$ 54, 2016, pp. 181-202; Impulsar la participación de los ciudadanos como factor de legitimidad en el proyecto de la integración europea, Cuadernos Europeos de Deusto, N. ${ }^{\circ} 60 / 2019$, pp. 157-185. 


\section{Derechos de autor}

Los derechos de autor (para la distribución, comunicación pública, reproducción e inclusión en bases de datos de indexación y repositorios institucionales) de esta publicación (Cuadernos Europeos de Deusto, CED) pertenecen a la editorial Universidad de Deusto. El acceso al contenido digital de cualquier número de Cuadernos Europeos de Deusto es gratuito inmediatamente después de su publicación. Los trabajos podrán leerse, descargarse, copiar y difundir en cualquier medio sin fines comerciales y según lo previsto por la ley; sin la previa autorización de la Editorial (Universidad de Deusto) o el autor. Así mismo, los trabajos editados en CED pueden ser publicados con posterioridad en otros medios o revistas, siempre que el autor indique con claridad y en la primera nota a pie de página que el trabajo se publicó por primera vez en CED, con indicación del número, año, páginas y DOI (si procede). Cualquier otro uso de su contenido en cualquier medio o formato, ahora conocido o desarrollado en el futuro, requiere el permiso previo por escrito del titular de los derechos de autor.

\section{Copyright}

Copyright (for distribution, public communication, reproduction and inclusion in indexation databases and institutional repositories) of this publication (Cuadernos Europeos de Deusto, CED) belongs to the publisher University of Deusto. Access to the digital content of any Issue of Cuadernos Europeos de Deusto is free upon its publication. The content can be read, downloaded, copied, and distributed freely in any medium only for non-commercial purposes and in accordance with any applicable copyright legislation, without prior permission from the copyright holder (University of Deusto) or the author. Thus, the content of CED can be subsequently published in other media or journals, as long as the author clearly indicates in the first footnote that the work was published in CED for the first time, indicating the Issue number, year, pages, and DOI (if applicable). Any other use of its content in any medium or format, now known or developed in the future, requires prior written permission of the copyright holder. 